\title{
Scrum Implementation for Online Transaction Processing (OLTP) in Hospital Management
}

\author{
Tedy Setiadi \\ Departement of Informatics \\ Universitas Ahmad Dahlan \\ Yogyakarta Indonesia \\ tedy.setiadi@tif.uad.ac.id
}

\author{
Syauqi Bima Premapasha \\ Departement of Informatics \\ Telkom University \\ Bandung Indonesia \\ syauqibima@hotmail.com
}

\begin{abstract}
The majority of e-class hospitals in Indonesia still apply manual, non-computerized systems to conduct operational activities every day. This causes problems especially for hospital directors, because as a director requires a system that can evaluate the operations of the hospital. This problem was initiated due to the data of operational activities that are currently available are not well managed. This happens because there is no system for employees so that employees have difficulty managing data from each process.

In this paper, we discuss Online Transaction Processing (OLTP) application development using the Scrum Framework. Scrum can address complex adaptive problems, by increasing productivity and creativity of all stakeholders involved. The test results with User Accepted Testing (UAT), Usability Testing and Scrum analysis based on the results of the development of the project show the OLTP system with the Scrum method has met the needs of the functional aspects and the development of the $\mathrm{X}$ hospital system
\end{abstract}

Keywords- E-class hospital, Online Transaction Processing (OLTP), Scrum, Evaluation

\section{INTRODUCTION}

The hospital is one of the most important institutions in Indonesia. Based on the quality of HR (Human Resources) and SDA (Resource Tool), hospitals are divided into 5 classes[1], Namely: hospital class A, class B, class C, class D, and class E. For the classification, from the beginning of the alphabet, hospital service quality is getting better.

All hospitals class A, B, C and D have applied Hospital Management Information System which includes adopting the concept of Online Transaction Processing (OLTP). The system serves to help the hospital staff running the work processes related to their operational activities. While the Eclass hospitals, including hospitals $\mathrm{X}$ yet to implement Hospital Management Information System, which means it is still using a manual system to perform all non-computerized their operations. The X hospital does not have an IT expert to lay on software development, it causes the need for development requirements can change rapidly and can not be predicted.
Based on information from the director of X Hospital, X Hospital had 34 employees. 26 people included nurses, doctors, receptionists, pharmacists and cashiers, the remaining 4 were administrators and hospital directors. X Hospital can service 40 - 70 patients every day and continue to increase in a 4-month cycle. According to the director of the hospital, this raises a new problem, because as a director of the hospital requires a system that serves to help evaluate hospital operations. The intended evaluation includes reports on the number of employees available, the number of patients visiting and the number of hospital admissions. This problem was initiated due to the data of operational activities that are currently available are not well managed. This happens because there is no information system for employees so that employees have difficulty managing data from each process. This has made it difficult for $\mathrm{X}$ Hospital to develop, as evidenced by obtaining E-class hospital categories.

To overcome these problems, a solution is needed, one of which is using the Online Transaction Processing (OLTP) approach which focuses on managing data changes optimally, these data are used as reporting used as an evaluation report for hospital directors [2]. In the case of the X Hospital, the data / facts referred to are reports on the results of evaluating hospital operational activities. For hospital directors, it will be helpful when evaluating all hospital operations because the available data is well managed by the system.

There are two approaches to building software systems, namely Waterfall based and Agile Development. In the case of the X hospital, the Agile Development approach will be used. This is because currently the need for software design for many companies / organizations must be more agile [3]. There are many agile development frameworks, in this study it was decided to use the Scrum framework. This is because the development of hospital systems is limited in terms of funds, human resources and time. Scrum can solve these problems [4]. After developing the Online Transaction Processing (OLTP) system, an evaluation will be made regarding the system's functionality by using User Acceptance Testing (UAT). Evaluation related to system effectiveness in terms of user satisfaction using Usability Testing. Scrum analysis is based on project development which includes analysis of funds, time and number of improvements. 


\section{RELATED WORK}

\section{A. Online Transaction Processing (OLTP)}

Online transaction processing, or OLTP, are a class of information systems that facilitate and manage transactionoriented applications, typically for data entry and retrieval processing. The term is somewhat ambiguous; Some understand the "transaction" in the context of computer or database transactions.Methods for analysis of the daily activities of companies that include (Insert, Update, Delete).OLTP systems stressing extremely fast query processing and keeping data integrityin a multi-access environment. For an OLTP system, effectiveness is measured by the number of transactions per second. OLTP database contains details of the current data.[5], OLAP and OLTP differences are described in table 1.

Table1. Differences OLAP and OLTP

\begin{tabular}{|c|c|c|}
\hline characteristics & OLAP & OLTP \\
\hline volatility & static Data & dynamic data \\
\hline Time & $\begin{array}{ll}\text { Current } & \text { and } \\
\text { historical data } & \\
\end{array}$ & The current data \\
\hline dimensional time & $\begin{array}{ll}\text { Explicit } & \text { and } \\
\text { variants }\end{array}$ & $\begin{array}{l}\text { Implicit and } \\
\text { current }\end{array}$ \\
\hline granularity & $\begin{array}{l}\text { Data aggregation } \\
\text { and consolidation }\end{array}$ & Data detailed \\
\hline Update & $\begin{array}{l}\text { Periodic and } \\
\text { regular }\end{array}$ & $\begin{array}{l}\text { Continuous and } \\
\text { regular }\end{array}$ \\
\hline Activity & Unpredictable & Repeatedly \\
\hline flexibility & High & Low \\
\hline performance & $\begin{array}{l}\text { Low to query } \\
\text { complex }\end{array}$ & $\begin{array}{l}\text { Height, } 1 \text { second } \\
\text { per query }\end{array}$ \\
\hline user & knowledge workers & employee \\
\hline Function & analysis & operational \\
\hline The intended use & $\begin{array}{ll}\text { queries } & \text { complex } \\
\text { and } & \text { decision } \\
\text { support } & \\
\end{array}$ & Transaction \\
\hline Priority & high flexibility & high-performance \\
\hline Metric & effective response & $\begin{array}{l}\text { The average } \\
\text { transaction }\end{array}$ \\
\hline Data size & $\begin{array}{l}\text { Gigabyte up to } \\
\text { terabytes }\end{array}$ & $\begin{array}{l}\text { megabyte up to } \\
\text { gigabytes }\end{array}$ \\
\hline
\end{tabular}

\section{B. Scrum}

Scrum is one of the frameworks agile development. Scrum can address complex adaptive problems, by increasing productivity and creativity of all stakeholders involved. Scrum is not a process or a technique for building products. Instead, Scrum is a framework that can use a variety of processes and techniques.[6].

Scrum uses an empirical methods, or in other words every stage in it involves inspection and adaptation. It indicates that the Scrum avoid more risk at the end of the project, which means saving project funds. Scrum also can adapt quickly to changes in the technical / business, then the technical requirements / business systems to be built prone to change.[7]

Scrum suitable for system development project consisting of 3-5 people. Also included are agile scrum which means the processing time required is relatively short project, so it will automatically save money and stakeholders.[12]

\section{User Acceptance Testing (UAT)}

User Acceptance Testing (UAT) is a testing methodology in which all users / clients involved in the test system to validate their system according to their needs. Needs to be adapted to the technical parameters, desais, business and management[13], UAT is also commonly known as the "last stage of testing" to ensure that user needs are met or not[14].

In the case of X hospital, UAT is used in the analysis of chapter 4 in which the entire user that includes directors, administrators, physicians, nurses, pharmacists and cashiers involved in the testing. The output of this process is UAT testing $\mathrm{X}$ hospital needs, whether it is fulfilled or not. The method used is the test case.

Test Case is a set of conditions or variables which the tester will determine if a tested system meets the requirements or work correctly [15], A test case is a document, which has a set of test data, preconditions, expected results and postconditions, developed for a specific test scenarios to verify compliance with certain requirements. Test case acts as a starting point for the implementation of the test, and after applying a set of input values, the application has a definitive outcome and leave the system at some point end or also known as postcondition execution [16], almost test case in the form of tables containing things that will be tested, the test scenario, output, expected results and its validation (is appropriate / no).

\section{PSSUQ (Post-Study System Usability Questionnaire)}

PSSUQ (Post-Study System Usability Questionnaire) is a package containing a questionnaire question as much as 16 to 19 questions. Packages question questionnaire has the objective to assess the satisfaction of users of the system were tested. Questions 1-16 states Overalls (Overall), questions 1-6 discuss System Quality, questions 7-12 discuss Information Quality discuss, questions 13-16 disscuss Interface Quality[17],

\section{DESIGN SYSTEM}

Section III discusses the system design methodology from the beginning - the end of the study. There are four main stages, but these stages are broken down back into 6 stages. For more details, fig. 1. describes the research methodology in outline. 


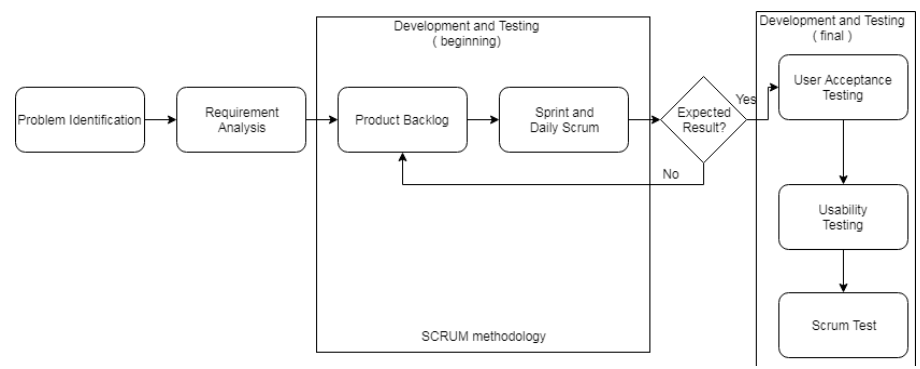

Fig 1. Research Methodology In Outline [8]

\section{A. Product Backlog}

Backlog is a fractional process will be based on a needs analysis functionality in the previous step. Based on a needs analysis step, the product backlog is divided into 7 user with role or respective tasks in accordance with its priorities (see table 2.)[9],[10].

The priority determines the sprint length (number of days) will be done in the next step. The higher its priority the longer sprint length (number of days) it. Priorities and sprint length (number of days) is determined by agreement between the director (Product Master) and leader of the design team (Project Manager). Pamareter reference is the technical complexity of the program in terms of its design and functionality[11]. The higher the level of its complexity, then the longer the amount of its day. For priority refers to the software Hansoft Scrum Project Management 9.2035, which is divided into four categories, namely:

a. Very High Priority: sprint length 12-14 days

b. High Priority: sprint length 10-12 days

c. Medium Priority: long sprint 7-9 days

d. Low Priority: long sprint 4-6 days

Table 2. Initial Product Backlog

\begin{tabular}{|c|c|c|c|}
\hline No. & product Backlog & Status & Priority \\
\hline \multirow[t]{4}{*}{1} & Administrator & not done & $\begin{array}{l}\text { Very High } \\
\text { Priority }\end{array}$ \\
\hline & Front page / login & not done & $\begin{array}{l}\text { Very High } \\
\text { Priority }\end{array}$ \\
\hline & admin dashboard & not done & $\begin{array}{l}\text { Very High } \\
\text { Priority }\end{array}$ \\
\hline & $\begin{array}{l}\text { CRUD user data for the } \\
\text { whole role }\end{array}$ & not done & $\begin{array}{l}\text { Very High } \\
\text { Priority }\end{array}$ \\
\hline \multirow[t]{4}{*}{2} & Doctor & not done & $\begin{array}{l}\text { medium } \\
\text { Priority }\end{array}$ \\
\hline & dashboard doctor & not done & $\begin{array}{l}\text { medium } \\
\text { Priority }\end{array}$ \\
\hline & $\begin{array}{l}\text { Seeing the patient medical } \\
\text { record data }\end{array}$ & not done & $\begin{array}{l}\text { medium } \\
\text { Priority }\end{array}$ \\
\hline & CRUD patient's prescription & not done & $\begin{array}{l}\text { medium } \\
\text { Priority }\end{array}$ \\
\hline \multirow[t]{6}{*}{3} & Receptionist & not done & High Priority \\
\hline & dashboard Front & not done & High Priority \\
\hline & CRUD new patient data & not done & High Priority \\
\hline & $\begin{array}{l}\text { CRUD outpatient } \\
\text { registration }\end{array}$ & not done & High Priority \\
\hline & $\begin{array}{l}\text { CRUD patient enrollment } \\
\text { ugd }\end{array}$ & not done & High Priority \\
\hline & $\begin{array}{c}\text { The serial number of queues } \\
\text { of outpatients }\end{array}$ & not done & High Priority \\
\hline
\end{tabular}

\begin{tabular}{|c|c|c|c|}
\hline No. & product Backlog & Status & Priority \\
\hline \multirow[t]{4}{*}{4} & Nurse & not done & $\begin{array}{l}\text { medium } \\
\text { Priority }\end{array}$ \\
\hline & dashboard nurse & not done & $\begin{array}{l}\text { medium } \\
\text { Priority }\end{array}$ \\
\hline & $\begin{array}{c}\text { The patient's medical record } \\
\text { data CRUD }\end{array}$ & not done & $\begin{array}{l}\text { medium } \\
\text { Priority }\end{array}$ \\
\hline & $\begin{array}{l}\text { Seeing the patient medical } \\
\text { record data }\end{array}$ & not done & $\begin{array}{l}\text { medium } \\
\text { Priority } \\
\end{array}$ \\
\hline \multirow[t]{3}{*}{5} & Cashier & not done & low Priority \\
\hline & dashboard cashier & not done & low Priority \\
\hline & $\begin{array}{l}\text { CRUD incoming and } \\
\text { outgoing transactions }\end{array}$ & not done & low Priority \\
\hline \multirow[t]{3}{*}{6} & Pharmacist & not done & $\begin{array}{l}\text { medium } \\
\text { Priority }\end{array}$ \\
\hline & dashboard pharmacist & not done & $\begin{array}{l}\text { medium } \\
\text { Priority }\end{array}$ \\
\hline & CRUD drug transaction data & not done & $\begin{array}{l}\text { medium } \\
\text { Priority }\end{array}$ \\
\hline \multirow[t]{3}{*}{7} & director & not done & $\begin{array}{l}\text { Very High } \\
\text { Priority }\end{array}$ \\
\hline & dashboard director & not done & $\begin{array}{l}\text { Very High } \\
\text { Priority }\end{array}$ \\
\hline & $\begin{array}{l}\text { Decisions regarding the } \\
\text { evaluation of hospital }\end{array}$ & not done & $\begin{array}{l}\text { Very High } \\
\text { Priority }\end{array}$ \\
\hline
\end{tabular}

\section{B. Sprint}

Sprint and daily Scrum is divided into 7 stages:

1. Sprint and daily Scrum administrator panel

2. Sprint and daily Scrum Front panel

3. Sprint and daily Scrum panel doctor

4. Sprint and daily Scrum nurse panel

5. Sprint and daily Scrum pharmacist panel

6. Sprint and daily Scrum cashier panel

7. Sprint and daily Scrum panel director

For each stage there are at least three processes, namely Sprint at the time of status in progress, completed the sprint at the time status and daily Scrum. Sprint made by stakeholders that include Project Manager, programmer 1 and programmers 2. Meanwhile, when the daily Scrum process testing blackbox testing by involving all stakeholders including the hospital director. That's because the hospital director has the authority to suspend / resume sprint, and that the project could be finished sooner.

Blackbox testing will generate an answer whether the system's functionality is appropriate or not. If the functionality of the system was appropriate and hospital directors are satisfied, it will proceed to the next sprint. If not, there will be daily Scrum 2nd, 3rd, etc until the functionality of the system is completely appropriate (see table 3 .).

Table 3. Questionnaire design

\begin{tabular}{|l|l|l|l|l|l|l|}
\hline \multirow{2}{*}{ No. } & \multicolumn{1}{|c|}{ Question } & \multicolumn{5}{c|}{ Likert scale } \\
\cline { 3 - 7 } & & $\mathbf{1}$ & $\mathbf{2}$ & $\mathbf{3}$ & $\mathbf{4}$ & $\mathbf{5}$ \\
\hline 1 & $\begin{array}{l}\text { Overall, I am satisfied with how } \\
\text { easy it is to use this system. }\end{array}$ & & & & & \\
\hline 2 & The system is easy to use & & & & & \\
\hline
\end{tabular}




\begin{tabular}{|c|c|c|c|c|c|c|}
\hline \multirow[t]{2}{*}{ No. } & \multirow[t]{2}{*}{ Question } & \multicolumn{5}{|c|}{ Likert scale } \\
\hline & & 1 & 2 & 3 & 4 & 5 \\
\hline 3 & $\begin{array}{l}\text { I can accomplish tasks and } \\
\text { Scenario. }\end{array}$ & & & & & \\
\hline 4 & I feel comfortable using this system. & & & & & \\
\hline 5 & This system is easy to learn & & & & & \\
\hline 6 & $\begin{array}{l}\text { I believe my work can be productive in a short } \\
\text { time by using this system }\end{array}$ & & & & & \\
\hline 7 & $\begin{array}{l}\text { This system gives an error message / error } \\
\text { that tells me how to correct the error }\end{array}$ & & & & & \\
\hline 8 & $\begin{array}{l}\text { When I made the mistake of using the } \\
\text { systems, easily and quickly I can get back to } \\
\text { the normal system. }\end{array}$ & & & & & \\
\hline 9 & $\begin{array}{l}\text { Information on this system are presented } \\
\text { clearly }\end{array}$ & & & & & \\
\hline 10 & $\begin{array}{l}\text { I can easily search for information } \\
\text { which are desired }\end{array}$ & & & & & \\
\hline 11 & $\begin{array}{l}\text { The information presented can effectively } \\
\text { help complete the tasks and scenarios }\end{array}$ & & & & & \\
\hline 12 & $\begin{array}{l}\text { Organization of the information displayed on } \\
\text { screen, presented clearly. }\end{array}$ & & & & & \\
\hline 13 & $\begin{array}{l}\text { The interface is presented feels comfortable } \\
\text { and } \\
\text { fun. }\end{array}$ & & & & & \\
\hline 14 & I like using the interface on this system. & & & & & \\
\hline 15 & $\begin{array}{l}\text { The system has the functions and capabilities } \\
\text { that I expected. }\end{array}$ & & & & & \\
\hline 16 & $\begin{array}{l}\text { Overall, I am satisfied to use } \\
\text { this system. }\end{array}$ & & & & & \\
\hline
\end{tabular}

\section{TESTING AND ANALYSIS}

\section{A. User Acceptance Testing (UAT)}

On the Administrator Panel, there are three product backlog that will be tested, namely Front page / login, CRUD for all user and admin dashboard. Results showed UAT is technically $100 \%$ output has been as expected (see table 4.)

Table 4. Testcase Administrator Panel

\begin{tabular}{|l|l|l|l|c|}
\hline No & $\begin{array}{l}\text { product } \\
\text { Backlog }\end{array}$ & Scenario & $\begin{array}{l}\text { Output is } \\
\text { expected }\end{array}$ & $\begin{array}{l}\text { Validat } \\
\text { ion }\end{array}$ \\
\hline 1 & $\begin{array}{l}\text { Front page } \\
/ \text { login }\end{array}$ & $\begin{array}{l}\text { Users enter a } \\
\text { username and } \\
\text { password correctly }\end{array}$ & $\begin{array}{l}\text { The page will } \\
\text { move to the } \\
\text { dashboard }\end{array}$ & $\checkmark$ \\
\cline { 3 - 5 } & $\begin{array}{l}\text { Users enter the } \\
\text { username and } \\
\text { password are } \\
\text { incorrect }\end{array}$ & $\begin{array}{l}\text { Will display a } \\
\text { warning } \\
\text { username and } \\
\text { password } \\
\text { wrong }\end{array}$ & $\checkmark$ \\
\hline 2 & $\begin{array}{l}\text { CRUD for } \\
\text { all users }\end{array}$ & $\begin{array}{l}\text { Test function to } \\
\text { create an account } \\
\text { receptionists, } \\
\text { doctors, nurses, } \\
\text { pharmacists, } \\
\text { cashier, director }\end{array}$ & $\begin{array}{l}\text { Function create } \\
\text { an account } \\
\text { goes well. All } \\
\text { accounts can } \\
\text { grow }\end{array}$ & $\checkmark$ \\
\hline
\end{tabular}

\begin{tabular}{|l|l|l|l|c|}
\hline No & $\begin{array}{l}\text { product } \\
\text { Backlog }\end{array}$ & Scenario & $\begin{array}{l}\text { Output is } \\
\text { expected }\end{array}$ & $\begin{array}{l}\text { Validat } \\
\text { ion }\end{array}$ \\
\hline & & $\begin{array}{l}\text { Users fill out the } \\
\text { form updates } \\
\text { receptionists, } \\
\text { doctors, nurses, } \\
\text { pharmacists, } \\
\text { cashier, director, } \\
\text { and then change } \\
\text { the data }\end{array}$ & $\begin{array}{l}\text { The selected } \\
\text { account data } \\
\text { receptionist } \\
\text { changed }\end{array}$ & $\checkmark$ \\
\hline & $\begin{array}{l}\text { Users searching } \\
\text { for data reception } \\
\text { by name in the } \\
\text { search box }\end{array}$ & $\begin{array}{l}\text { Will perform } \\
\text { user search } \\
\text { results }\end{array}$ & $\checkmark$ \\
\hline 3 & $\begin{array}{l}\text { Users delete data } \\
\text { reception }\end{array}$ & $\begin{array}{l}\text { Receptionist } \\
\text { account data } \\
\text { will be deleted }\end{array}$ & $\checkmark$ \\
\hline
\end{tabular}

Each functionality of the Director Panel runs successfully and is technically in accordance with the wishes of the user.

\section{B. Usability Testing}

After getting the average value of each question. The next step is to calculate the average of each question. Questions 1-6 covers aspects of System Quality, questions 7-12 covers aspects of Information Quality, questions 13-16 covers aspects Interface Quality. Then the value of each of these aspects back in the average to obtain the overall value (Overall). Below is a table 5. that shows average every aspect:

Table5. Average Every Aspect

\begin{tabular}{|l|c|}
\hline \multicolumn{1}{|c|}{ Aspect } & Score \\
\hline system Quality & $4: 43$ \\
\hline information Quality & $3: 57$ \\
\hline interface Quality & 3.82 \\
\hline Overall & 3.94 \\
\hline
\end{tabular}

Based on the above results, the lowest average score was 3:57, namely on aspects of Information Quality. Aspects of Information Quality to get the low score is due to several factors, among others, the information displayed is not effective and the organization of the information displayed is not clear. This causes the user difficulty in obtaining the information needed. However, a score of Information Quality is still above the median value 2.5 , it shows the Information Quality generated is still quite good and not so affect the value of 3:57. The highest average score is 4.43 which is the aspect of the Quality System. It shows that the system is easy to use and useful system for the user to support his work. Aspect Quality Interface obtain an average score of 3.82 .

Overall system to get a score average (mean) of 3.94 which showed above the middle value 2.5 . It shows the average user is satisfied with the overall system.

Table 6. Respondents answer Results Table

\begin{tabular}{|l|c|}
\hline \multicolumn{1}{|c|}{ Aspect } & $\begin{array}{c}\text { Score } \\
(\text { In \%) }\end{array}$ \\
\hline system Quality & 88.75 \\
\hline
\end{tabular}




\begin{tabular}{|l|l|}
\hline information Quality & 71.45 \\
\hline interface Quality & 76.56 \\
\hline Overall & 78.92 \\
\hline
\end{tabular}

Based on the results in table 4-11 explained that the System Quality obtain a score of $88.75 \%$ has been agreed with quality user-owned systems, Information Quality to get the low score that is $71.45 \%$ but still a category that agree / well, Interface Quality obtain a score of $76.56 \%$ and Overall in the system has a score of $78.92 \%$, which according to the Likert scale results table in the category Agree, Neither, or the like.

\section{The analysis is based on the development project by Scrum}

This timeline analysis aims to calculate the total time of the whole project from start-finish. Based on a needs analysis project in chapter 3, when designing Online Transaction Processing (OLTP) $\mathrm{X}$ hospital is 3 months. In reality, the time for system design Online Transaction Processing (OLTP) is 84 days.

Broadly speaking, the time is divided into two, namely the design time which is divided into seven sessions and a daily Scrum (evaluation). The details are as follows:
a. Admin Panel: 14 days (04/06/2017 - 20/04/2017)
b. Receptionist Panel: 10 days (04/24/2017 - 04/05/2017)
c. Physician Panel: 7 days $(05 / 07 / 2017$ - 05/14/2017)
d. Nurse Panel: 7 days (16/05/2017 - 23/05/2017)
e. Pharmacists Panel: 7 days $(25 / 05 / 2017$ - 06/02/2017)
f. The cashier Panel: 5 days (06/05/2017 - 10/06/2017)
g. Director of Panel: 12 days (06/12/2017 - 24/06/2017)
h. Total Time Design: 62 days
i. Total Time Daily Scrum: 22 days
j. Total Time Project of the open-ended: 84 days (06/04/2017 - 06/29/2017).

\section{CONCLUSIONS}

Based on the research that has been done, it can be concluded as follows:

1. Has been produced by the system Online Transaction Processing (OLTP) built using the Scrum method. The system generates a 7 panel is divided into panels administrator, director of the panel, a panel of nurses, cashiers panel, Panel pharmacist, physician panel and front panel. Administrator panel serves to manage the overall system. Director of the panel serves to receive reports on the number of employees, transactions and patient. Nurses panel serves to manage the patient's medical record. The cashier panel serves to manage transaction data. Pharmacists panel serves to administer a drug transaction data. Doctors panel serves to manage patient care data. Receptionist panel serves to manage patient registration data is old / new.

2. Evaluations have been conducted using the User Acceptance Testing (UAT) to test the functionality of the system and Usability Testing to test user satisfaction.
Results of testing User Acceptance Testing (UAT) method shows $100 \%$ testcase product backlog of test scenarios produce invalid output. It shows in functionality of the system is going according to the user wishes. The test results Usability Testing by questionnaire PSSUQ (PostStudy System Usability Questionnaire) showed that the overall average value system is 3.94 (above the median value 2.5) and the value of $78.92 \%$ indicates user satisfaction agree. Based on the Likert scale table, it shows that in broad outline the user is satisfied with the system that has been built.

Evaluations have been conducted to measure the effectiveness of Scrum. The evaluation includes an analysis based on a timeline, an analysis based on the expenditure of funds and analysis based on improvement of the system. The evaluation results showed Scrum can meet the design requirements are limited in terms of time, it is indicated by the design time is below the target time. The evaluation results show the fund expenditure by Scrum can save on expenditures for payment every count sprint, which means the fund is well manageable. The evaluation results showed Scrum based repair system quickly to changes and Scrum are static, meaning that if there is a product backlog that change will not influence other product backlog.

\section{REFERENCES}

[1]. D. Supriyadi, "Number of Bandung City Hospital."Available:http://www.jabarprov.go.id/inde x.php/pages/id/400. [Accessed: 12-Oct-2016].

[2] MS Sangari and J. Razmi, "Business intelligence competence, agile capabilities, and agile performance in the supply chain," Etc. Tehran, Vol. 26, p. 2, Jul. 2014.

[3] M. Michael and S. Traian, "Agile BI - The Future of BI," Acad. Econ. Stud. Buchar. Rom., Vol. 17, 2013.

[4] "Why Scrum? The 6 Very Real Benefits of Agile. "[Online]. Available:

http://www.innolution.com/blog/why-scrum-the-6very-real-benefits-of-agile. [Accessed: 03-Dec-2017].

[5] K. Schwaber and J. Sutherland, The Scrum Guide. The Definitive Guide to Scrum: The Rules of the Game, 2013.

[6] IPD Lesmana and RN Karimah, "Waterfall Agile Hybrid for Preventation Information System of Dengue Viral Infections: A Case Study in the Health Department of Jember, East Java, Indonesia, "Fourteenth Int. Conf. ICT Knowl. Eng., 2016.

[7] "Agile Business Intelligence How to Make It Happen." Capgemini.

[8] H. Kniberg, Scrum and XP Practical "How do we implement Scrum." C4Media, Publisher of InfoQ.com 2007.

[9] "Daily Scrum Personas," 26-May-2017. [On line]. Available: https://agilefellow.com/2016/06/30/dailyscrum-personas/.

[10] M. Rouse, "model-view-controller (MVC)," 26-May2017.[On line]. Available: 
http://whatis.techtarget.com/definition/model-viewcontroller-MVC.

[11] "MVC Framework - Introduction," 26-May-2017. [On line]. Available:

https://www.tutorialspoint.com/mvc framework/mvc framework introduction.htm.

[12] "Six Benefits of Using MVC Model for Effective Web Application Development," 26-May-2017. [On line]. Available: https://www.brainvire.com/sixbenefits-of-using-mvc-model-for-effective-webapplication-development/.

[13] "User Acceptance," in SDLC: Related Links,.

[14] M. Bolton, "User Acceptance Testing." Developsense.com.

[15] "Test Case Fundamentals." [On line]. Available: http://softwaretestingfundamentals.com/test-case/. [Accessed: 06-May-2017].

[16] "Test Case," 16-Oct-2016. [On line]. Available: http://sis.binus.ac.id/2016/12/16/test-case/. [Accessed: 06-May-2017].

[17] "Chapter 4: Questionnaire Design." [On line]. Available: http://www.fao.org/docrep/w3241e/w324le05.htm. [Accessed: 25-Jul-2017]. 